\title{
Treatment of Gastric Ulcers with Fenugreek Seed Extract; In Vitro, In Vivo and In Silico Approaches
}

\author{
BRINAL FIGER, R. PISSURLENKAR ${ }^{1}$, PREMLATA AMBRE, SAMIDHA KALEKAR², RENUKA MUNSHI², MANJUSHA \\ GATNE $^{3}$ AND VAISHALI SHIRSAT*
}

Department of Pharmaceutical Chemistry, Bombay College of Pharmacy, Kalina, Mumbai-400 098, Molecular Simulations Group, ${ }^{1}$ Department of Pharmaceutical Chemistry, Goa College of Pharmacy, Panaji, Goa-403 001, ${ }^{2}$ Department of Clinical Pharmacology, Topiwala National Medical College and B. Y. L Nair Charitable Hospital, Dr. A. L. Nair Road, Mumbai-400 008, ${ }^{3}$ Department of Pharmacology and Toxicology, Bombay Veterinary College, BVC Campus Road, Parel, Mumbai-400 012, India

Figer, et al.: Fenugreek Seed Extract for Gastric Ulcers

\begin{abstract}
The objective of the present study was to evaluate the antiulcer or gastroprotective potential of fenugreek seed aqueous extract using in vitro and in vivo models and to elucidate the possible mechanism of fenugreek seeds by in silico analysis on $\mathrm{H}^{+} / \mathrm{K}^{+}$ATPase receptor, a crucial target for mediating the gastroprotective effect. Human gastric carcinoma epithelial cell line was used as an in vitro model to study the gastro protective effect of fenugreek aqueous extract over a concentration range of $0.1-10 \mu \mathrm{g} / \mathrm{ml}$ by 3-(4,5-dimethylthiazol2-YI)-2,5-diphenyltetrazolium bromide assay against ethanol (15\%). In vivo gastroprotective effect of the extract was assessed in adult Sprague Dawley rats of either sex at three doses viz., 200,600 and $1000 \mathrm{mg} / \mathrm{kg}$ against ethanol $(90 \%)$. Pantoprazole sodium $(50 \mathrm{mg} / \mathrm{kg})$ and misoprostol sodium $(20 \mu \mathrm{g} / \mathrm{kg}) \mathrm{were}$ used as positive control. The flavonoids and saponins reported in the extract were assessed for possible interactions at $\mathrm{H}^{+} / \mathrm{K}^{+}$ATPase receptor site by in silico analysis. In the human gastric carcinoma epithelial cells, Fenugreek protected against the damage induced by ethanol at $5 \mu \mathrm{g} / \mathrm{ml}$; whereas a protection of $67 \%$ at the dose of $1000 \mathrm{mg} / \mathrm{kg}$ was observed in the animal studies. The flavonoid derivatives namely vitexin-7-O-glucoside, vicenin-2, orientin and luteolin showed good interactions on $\mathrm{H}^{+} / \mathrm{K}^{+}$ATPase while the saponins lacked good interaction in in silico analysis. Fenugreek seed extract showed gastroprotection in both: in vitro and in vivo studies. The possible mechanism of action for the extract was elucidated by in silico studies.
\end{abstract}

Key words: Fenugreek, AGS cell line, ulcer index, flavonoids, saponins, $\mathrm{H}^{+} / \mathrm{K}^{+}$ATPase

Fenugreek (Trigonella foenum-graecum, Family: Fabaceae) is a commonly used condiment and spice in Indian household. The plant seeds are reported to be of significant medicinal values with its high flavonoid, phenol, saponin and amino acid content ${ }^{[1]}$. The antiulcer activity of aqueous and gel fraction has been demonstrated in several animal models ${ }^{[2-4]}$. Though these studies have stated several mechanisms behind its gastroprotective effect, most have relied on the use of in vivo method.

There have been some studies, which reported use of in vitro models like the human gastric carcinoma epithelial cell line (AGS), which is a well-established model and has characteristics of normal gastric epithelial cells ${ }^{[5]}$. However, such a model was never used for evaluating the gastroprotective effect in case of herbal extracts. Development of an in vitro model for evaluating gastroprotection in herbals can

${ }^{*}$ Address for correspondence

E-mail: vashirsat@gmail.com

September-October 2017 help reduce the use of large number of experimental animals and the arduous procedure of obtaining ethics committee approvals for the same. In order to take an initiative in this regard it is necessary to have results in in vitro model; results of which are comparable to those obtained in in vivo.

Elucidation of mechanisms of herbs with substantial experimental evidence involves the isolation and testing of each component for the specific target proposed, which is a time consuming process. Use of in silico approaches like docking is useful in characterization of the possible interaction and thereby elucidating the

This is an open access article distributed under the terms of the Creative Commons Attribution-NonCommercial-ShareAlike 3.0 License, which allows others to remix, tweak, and build upon the work non-commercially, as long as the author is credited and the new creations are licensed under the identical terms

Accepted 16 July 2017

Revised 07 February 2017

Received 24 July 2016

Indian J Pharm Sci 2017;79(5):724-730 
binding mode between the herbal constituents with the proposed site of action (enzyme or the receptor) ${ }^{[6,7]}$. Unfortunately, a combined approach involving in vitro, in vivo and in silico has been rarely used to study the therapeutic action in case of herbals.

Taking these limitations into consideration, we conducted the present study to evaluate and compare the cytoprotective effect of aqueous extract of fenugreek plant seeds in both in vitro and in vivo models so as to determine if similar results are obtained using both the models. Also, through this study we aimed to elucidate and support the possible mechanism of action for fenugreek seed extract, by assessing the interactions of in silico analysis for the major reported constituents on $\mathrm{H}^{+} / \mathrm{K}^{+}$ATPase a receptor crucial in mediating gastroprotective effect.

The combined approach of in vitro and in vivo evaluation supported with in silico analysis in characterization of the biological activity will thus aid us in proposing the mechanism of fenugreek, which can further help in identifying safer and cost effective alternatives for treating gastric ulcers.

\section{MATERIALS AND METHODS}

Soxhlet apparatus (J-Sil, India), Ham's F-12 medium, fetal bovine serum (Invitrogen, USA), tissue culture flasks (BD Falcon, USA), misoprostol sodium as misoprost tablets (Cipla Ltd, India), ethanol (CDH Ltd, India), petroleum ether and sodium bicarbonate (S. D. Fine-Chem Ltd, India), pantoprazole sodium (Blue Cross Labs Pvt. Ltd, Mumbai).

\section{Preparation of the extract:}

The seeds of $T$. foenum-graecum were procured from Namdeo Umaji Agritech Pvt. Ltd. Mumbai and were deposited in a herbarium for authentication (sample specimen no: bhf 140611a). Finely ground seed powder was extracted using Soxhlet extraction apparatus by defatting with petroleum ether initially and then by extracting with distilled water. The extract obtained was tested chemically for the presence of various phytoconstituents ${ }^{[8]}$.

Phytochemical screening of the extract was done to ascertain presence of flavonoids along with other phytoconstituents like saponins and amino acids. Diosgenin, a sapogenin was used as the marker compound for the extract. Since diosgenin exists in conjugation with aglycone moiety, hydrolysis of the extract with $2 \mathrm{~N} \mathrm{HCl}$ was performed and partitioned using chloroform. Detection and quantification of diosgenin was then done by HPTLC densitometry using Camag HPTLC system III, WinCATs software and precoated silica Gel $60 \mathrm{~F}_{254}$ (Merck) TLC plates as the stationary phase. The sample applications were done using a Hamilton syringe $(100 \mu \mathrm{l})$, Linomat 5 applicator with sample band length of $8 \mathrm{~mm}$ and migration distance of $180 \mathrm{~mm}$. The mobile phase used was petroleum ether: isopropanol (9:1) with a detection wavelength of $430 \mathrm{~nm}$. The bands were detected using anisaldehyde sulphuric acid as the derivatizing agent. The Rf of diosgenin spot was found to be 0.5 .

\section{In vitro studies on fenugreek aqueous extract:}

AGS cell line was procured from National Centre for Cell Sciences (NCCS), Pune. Cells were incubated in Ham's F-12 medium containing $100 \mathrm{mg} / \mathrm{l}$ of penicillin, $150 \mathrm{mg} / \mathrm{l}$ of azithromycin, $1.2 \mathrm{~g} / 1$ of sodium bicarbonate and $10 \%$ foetal bovine serum. The cell monolayer was subcultured in a $25 \mathrm{~cm}^{2}$ flask at 1:5 ratios every $72 \mathrm{~h}$ by treatment with $0.1 \%$ trypsin and $0.03 \%$ ethylenediaminetetraacetic acid (EDTA). Cells were grown in an incubator with $5 \% \mathrm{CO}_{2}$ at $37^{\circ}$. Cell passage was maintained in a range of 25-40 for experimentation.

The aqueous extract of fenugreek was evaluated over a concentration range of 0.1 to $400 \mu \mathrm{g} / \mathrm{ml}$ against $15 \%$ ethanol as an ulcerogen. The concentration of ethanol to induce damage was obtained after standardization (fig. 1A). The concentrations used were extrapolated from the reported human dose of fenugreek (Nature's Way ${ }^{\circledR}$ Fenugreek seed capsules). The effect on cell viability was assessed by colorimetric assay using 3-(4,5-dimethylthiazol-2-yl)-2,5-diphenyl tetrazolium bromide (MTT, fig. 1). The cells were seeded (density of $40 \times 10^{3}$ cells $/ \mathrm{ml}$ ) in 96 well plate followed by treatment with different concentrations of the extract. The plate was incubated for $24 \mathrm{~h}$ with $5 \% \mathrm{CO}_{2}$ at $37^{\circ}$. Following incubation, MTT was added for $4 \mathrm{~h}$ followed by the addition of $\mathrm{HCl}$ :isopropanol $(1: 24)$; in order to lyse the cells and solubilize the formazan crystals. The absorbance of the resulting solution was read using an enzyme-linked immunosorbent assay (ELISA) plate reader at a wavelength of $570 \mathrm{~nm}$. The amount of colour produced was directly proportional to the number of viable cells. Concentrations of the extracts which did not affect the cell viability were further selected for evaluating the cytoprotective activity.

To determine the maximum effect of ethanol as ulcerogen on AGS cells, the cells were incubated in serum free medium containing $0-15 \% \mathrm{v} / \mathrm{v}$ ethanol for 
A.

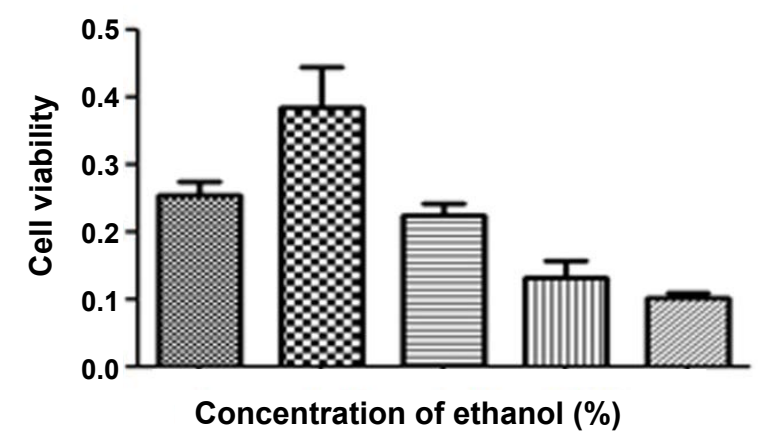

B.

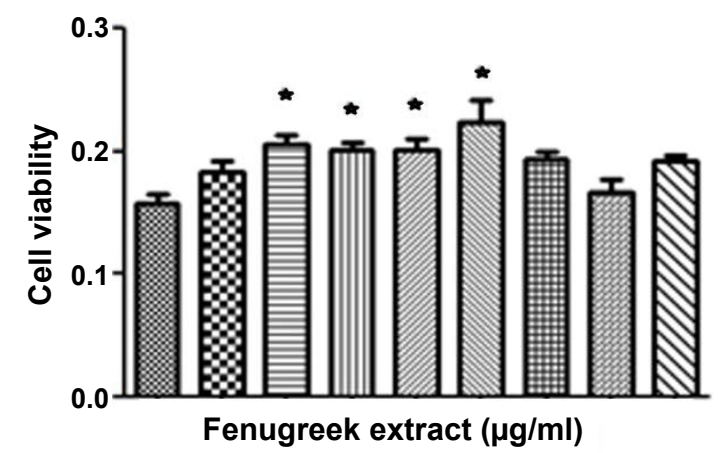

Fig. 1: Cell viability assay

(A) Standardization of ethanol concentration for cell viability, control, $25 \%, \equiv 10 \%$, IIII $12.50 \%$, $\% 15 \%$. (B) Effect of extract concentration on cell viability against ethanol-induced damage, ethanol control, $20.1 \mu \mathrm{g} / \mathrm{ml}, \equiv 0.5 \mu \mathrm{g} / \mathrm{ml}, 111 \mathrm{l} 1 \mu \mathrm{g} / \mathrm{ml}, \dddot{2} .5 \mu \mathrm{g} / \mathrm{ml}$, $5 \mu \mathrm{g} / \mathrm{ml}$, $7.5 \mu \mathrm{g} / \mathrm{ml}, \approx \times 10 \mu \mathrm{g} / \mathrm{ml}, \ldots$ standard. (Data represented as mean \pm SEM for $\mathrm{n}=6$. *Indicates significance with respect to ethanol treated positive control at $\mathrm{P}<0.05$, using one way ANOVA with Turkey multiple comparison test)

30 min. Following incubation, viability of the cells was assayed using MTT assay. The concentration inducing maximum damage was further used to study cytoprotective effect of the extracts.

AGS cells were seeded in 96 well plates with cell density of $4 \times 10^{3}$ cells/well followed by treatment with various concentrations of the extracts over a range $0.1-10 \mu \mathrm{g} / \mathrm{ml}$ for $24 \mathrm{~h}$. The cytoprotective role of the extracts against ethanol was assayed by exposing the treated AGS cells to $15 \%$ ethanol for $30 \mathrm{~min}$. After exposure the cell viability was measured using MTT assay. AGS cells treated only with ethanol served as control to assess the cytoprotective effect. Based on the similarity for the mechanism of action, misoprostol sodium a prostaglandin analogue was used as a reference standard for evaluating cytoprotective activity of fenugreek phytoconstituents against ethanol damage.

\section{In vivo studies for evaluation of gastroprotection in ethanol-induced ulcer model:}

Sprague Dawley rats (nos-84) in weight range 150-250 g were used for study. The protocol for in vivo studies was approved by the animal ethics committee and was prepared as per committee for the purpose of control and supervision of experiments on animals (CPCSEA) guidelines (MVC/IAEC/10/2012).

Animals fasted for over $24 \mathrm{~h}$ were administered with the extract suspension in doses of 200,600 and $1000 \mathrm{mg} / \mathrm{kg}$. An hour later, ethanol (90\%) was administered orally. After $1 \mathrm{~h}$ the animals were euthanized by injecting xylazine ketamine. The euthanized animals were dissected and stomachs were opened along greater curvature. The gastric juice was collected and the stomach was washed with saline and examined for the presence of ulcers. The ulcer index, curative ratio, $\mathrm{pH}$, and titratable acidity were measured for the gastro protective assessment parameters ${ }^{[2,4,9]}$. Two reference standards having different gastroprotection mechanism: pantoprazole sodium, a proton pump inhibitor (causes reduction of gastric acidity) and misoprostol sodium, a prostaglandin analogue (offers mucosal protection) were used for gastroprotective comparison. The histopathology of sample was performed by embedding tissue sample of each of the study groups in paraffin and cross sections of $4 \mu \mathrm{m}$ were taken using a microtome. The sections were stained using eosin and haematoxylin and observed under the electron microscope of resolution of $100 x$.

The results obtained for in vitro and in vivo were expressed as \pm SEM. The data was evaluated by using one way ANOVA (Tukey multiple comparison test) for in vitro study and paired t-test for in vivo studies. Value of $\mathrm{P}<0.05$ was considered to be statistically significant.

\section{In silico computational studies:}

The docking studies of the fenugreek constituents with the binding site of $\mathrm{H}^{+} / \mathrm{K}^{+}$ATPase receptor was performed using Surflex-1.3 module in Sybyl-X 2.0 Suite ${ }^{[10]}$. Since experimentally determined structure of $\mathrm{H}^{+} / \mathrm{K}^{+}$ATPase pump was not available, it was built using the principles of comparative protein modelling in Modeller 9v9 $9^{[9,11-13]}$. The template sequences of structures, sodium-potassium pump $\left(\mathrm{Na}^{+} / \mathrm{K}^{+}\right.$-ATPase $)$ and gastric $\mathrm{H}^{+} / \mathrm{K}^{+}$-ATPase (PDB code $3 \mathrm{~A} 3 \mathrm{Y}$ and 2XZB, respectively) were obtained from the protein data bank ${ }^{[10]}$ and aligned using Clustal $X 2^{[14]}$. The 
sequence similarity of $62 \%$ was observed between the query and the template sequences, which is considered as acceptable to proceed with the homology modelling. The best model was chosen based on De-optimized potential energy (DOPE score) ${ }^{[11]}$ and profile- $3 \mathrm{D}^{[15]}$ scores and Ramachandran's plot of the models. The best model thus selected was prepared using the protein preparation wizard workflow in the Schrödinger Suite 2010.

The 3D model of $\mathrm{H}^{+} / \mathrm{K}^{+}$-ATPase pump was minimized using molecular dynamics simulations (MDS). Prior to MDS the model was embedded in dipalmitoyl phosphatidylcholine (DPPC) membranes based on the co-ordinates provided by orientation of proteins in membrane database (OPM) and then soaked in TIP3P water explicit model ${ }^{[16]}$. The salt concentration of the system was adjusted to $0.15 \mathrm{M}$ of $\mathrm{NaCl}$ by adding appropriate $\mathrm{Na}^{+}$and $\mathrm{Cl}^{-}$ions. This generated the system necessary to carry out the MDS. The system was then relaxed using NPT relax protocol for transmembrane proteins in Desmond. Subsequently the system was simulated for $5 \mathrm{~ns}$, with the temperature of the system maintained at $323 \mathrm{~K}$ by coupling to an external temperature bath based on the Berendsen algorithm. Initial velocities were generated randomly from a Maxwell distribution at $323 \mathrm{~K}$ in accordance with the masses assigned to the atoms. The trajectories and corresponding energies were sampled every 5 ps.

The ligands of the fenugreek constituents selected for docking were mainly flavonoids and saponins i.e. vitexin-7-O-glucoside, vicenin-2, vicenin-2, orientin, luteolin, naringenin, quercetin, diosgenin, yamogenin, yuccagenin, tigogenin and smilagenin. The active site of amino acids reported in the literature for $\mathrm{H}^{+} / \mathrm{K}^{+}$ ATPase ${ }^{[17,18]}$ is with respect to ligands $\mathrm{SCH} 28080$ and oubain, respectively. The amino acid residues found important in the active site of $\mathrm{H}^{+} / \mathrm{K}^{+}$ATPase pump were: $\mathrm{Val}^{344}, \mathrm{Ala}^{345}$, $\mathrm{Phe}^{338}$, Gly ${ }^{341}$, $\mathrm{Phe}^{805}, \mathrm{Thr}^{819}, \mathrm{Asp}^{334}$, $\mathrm{Tyr}^{808}, \mathrm{Arg}^{902}$ and $\mathrm{Asp}^{908}$. The SurFlex docking protocol was employed to dock the said ligand, which is based on an incremental construction of the ligands in the active site of the protein. A set of diverse poses were obtained based on the ranking by the inbuilt empirical scoring function of SurFlex ${ }^{[19,20]}$.

\section{RESULTS AND DISCUSSION}

Phytochemical assessment indicated presence of flavonoids, saponins and phenols (Table 1). In in vitro studies on fenugreek aqueous extract showed statistically significant inhibition of cell death (fig. 1A) at concentrations of $0.5,1.0,2.5$ and 5.0 $\mu \mathrm{g} / \mathrm{ml}$. The extract was also found to exhibit better in vitro cytoprotective activity than misoprostol sodium (reference standard) against ethanol-induced damage to the cells (fig. 1B). A decrease in the activity of the extract was observed beyond the concentration of $5.0 \mu \mathrm{g} / \mathrm{ml}$.

In in vivo model, a positive correlation existed between the doses of extract and protective response i.e. an increase in protection with increase in dose was observed. The most effective concentration of $1000 \mathrm{mg} / \mathrm{kg}$ of extract was found to prevent ulcer lesions completely (fig. 2). However, an increase in titrable acidity was seen at high dose. Similarly the $\mathrm{pH}$ increased towards the acidic range at the protective dose of $1000 \mathrm{mg} / \mathrm{kg}$. Curative ratio indicated $67 \%$ protection with respect to positive control group. The extract exhibited better gastric acidity reduction and mucosal protection effect in comparison to reference standards-pantoprazole sodium and misoprostol sodium against ethanol as an ulcerogen (Table 2).

In in silico model, flavonoid constituents like vitexin-7-O-glucoside, vicenin-1, luteolin and orientin were found to show good binding, with $\mathrm{H}^{+} / \mathrm{K}^{+}$ATPase

TABLE 1: PHYTOCHEMICAL PARAMETERS

\begin{tabular}{lc}
\hline Phytochemical parameter & Value \\
\hline Water soluble extractive value & $36.80 \%$ \\
Total flavonoid content & $\begin{array}{c}10.54 \mathrm{mg} / \mathrm{g} \text { of } \\
\text { extract }\end{array}$ \\
Total phenolic content determined & $\begin{array}{c}65.82 \mathrm{mg} / \mathrm{g} \text { of } \\
\text { extract }\end{array}$ \\
as mg equivalent of gallic acid & $20.56 \%$ \\
Percent content of total saponins in & $3.80 \%$ \\
hydrolysed extract & \\
Diosgenin content in total saponins &
\end{tabular}

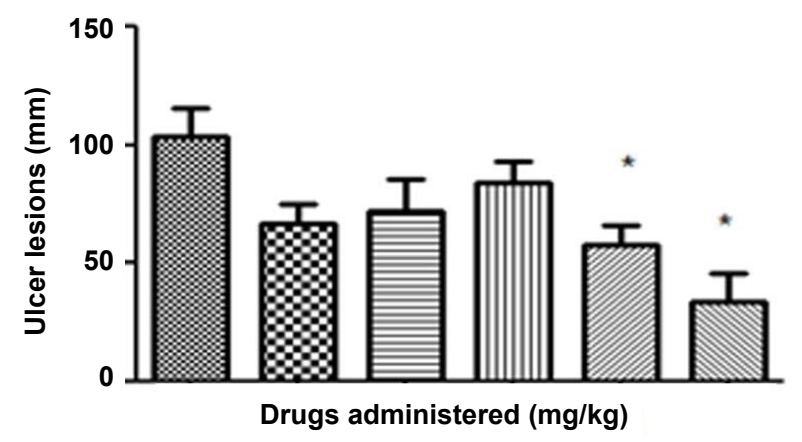

Fig. 2: Effect of fenugreek extract against ethanol-induced damage in rats

Positive control, $₹$ standard I (pantaprazole), $\equiv$ standard II (misoprostol), IIII low dose $(200 \mathrm{mg} / \mathrm{kg})$, W medium dose $(600$ $\mathrm{mg} / \mathrm{kg})$, w high dose $(1000 \mathrm{mg} / \mathrm{kg})$. High dose was found to be most effective in reducing lesions (Data represents \pm SEM for $\mathrm{n}=6$. *Indicates significance with respect to positive control group at $\mathbf{P}<0.05$, using paired $t$ test for all treatment groups) 
as compared to other compounds (Table 3). Diosgenin, which was used as a biomarker was found to show moderate binding. The key amino acids involved in interaction were mainly $\mathrm{Ile}^{337}, \mathrm{Ile}^{340}, \mathrm{Asp}^{334}, \mathrm{Asn}^{143}$, $\mathrm{Asn}^{144}$ and $\mathrm{Gly}^{133}$ (fig. 3). Also the presence of hydroxyl groups on the glycosidic scaffold was found to contribute significantly to the overall polar interactions shown by the compounds.

The present study aims to establish a correlation between in vivo, in vitro and in silico approaches for predicting gastroprotection of fenugreek seed extract. The AGS cell line used in vitro closely mimics the gastric epithelial lining in vivo and thus it was easier to correlate the response elicited by the extract. A dose-dependent increase in cytoprotection was seen in vitro with an increase in the concentration of the fenugreek aqueous extract. The damage induced by ethanol in vitro is through generation of toxic free radicals $^{[21]}$ and presence of phytoconstituents like flavonoids and saponins, which exhibit antioxidant and gastroprotective activity ${ }^{[22,23]}$ in the extract, could have contributed to this protective response. The possible free radical scavenging effect of the extract observed in vitro is in sync with a study conducted by Madhava et al., who found up to $70 \%$ free radical scavenging activity in fenugreek extracts ${ }^{[24]}$.

In in vivo model similarly, the gastroprotective activity was observed at higher doses with significant reduction in ulcer lesions. However, at the highest protective dose $(1000 \mathrm{mg} / \mathrm{kg})$ an increase in acidic $\mathrm{pH}$ and titrable acidity was seen. This possibly indicates that the protective mechanisms of the extract were not based solely on alteration of $\mathrm{pH}$ or a decrease in titrable acidity. A close understanding of the mechanism behind ethanol-induced damage based on previous reports shows that the detrimental effect of ethanol on gastric mucus is not due to an increased secretion of gastric acid ${ }^{[25]}$, but due to an alteration in the permeability of the gastric mucus by interference with the activity of cyclic AMP. The extract exhibited good mucosal protective effect as there was an increase in total mucosal weight in treated groups as compared to the ethanol group. The aqueous extract being rich in presence of galactomannans could have formed a protective barrier around the gastric epithelial lining, as galactomannans have been reported to possess mucosal protective effect ${ }^{[26]}$. Also, a significant reduction in the degree of degeneration, necrosis and inflammation on treatment with the extract in vivo indicates a possible role as an antiinflammatory and antisecretory agent apart from mucus protection which is in sync with the observation of previously published reports ${ }^{[2]}$. The antisecretory mechanisms suggested for the extract could possibly involve certain key receptors like the $\mathrm{H}^{+} / \mathrm{K}^{+}$ATPase. Interestingly, key flavonoid constituents reported to be present in the extract like vitexin-7-Oglucoside, vicenin-1, luteolin and orientin have shown remarkable degree of interaction with $\mathrm{H}^{+} / \mathrm{K}^{+}$ATPase receptor binding site in silico (fig. 4).

The extract tested positive for the presence of flavonoids. The in vitro gastroprotective activity of fenugreek extract can be attributed to the free radical scavenging effect of the extract on the AGS cell line. The in vivo studies in rats suggested that the extract due to the presence of galactomannans formed a protective barrier over the gastric epithelial lining and thus exhibited a good mucosal protective effect. Findings from in vivo studies also suggested that the gastroprotective mechanism was not attributed solely due to alteration of gastric $\mathrm{pH}$ or acidity. The gastroprotective response of the extract was consistent in both in vitro and in vivo models. The crude form of the extract is an amalgam of a series of phytoconstituents, each individually possessing a therapeutic value with the possibility of synergism. Thus, to avoid the arduous, time consuming and expensive process of isolation of each component, in silico analysis after confirming activity through in vitro and in vivo models is, in our view, appropriate.

TABLE 2: GASTROPROTECTION OBSERVED IN VARIOUS GROUPS OF RATS IN ETHANOL-INDUCED ULCER MODEL

\begin{tabular}{|c|c|c|c|c|}
\hline Groups (dose administered in rats per body weight) & $\begin{array}{l}\text { Ulcer index } \\
(\mathrm{mm})\end{array}$ & $\begin{array}{c}\text { Curative ratio } \\
\text { (\%) }\end{array}$ & $\begin{array}{c}\text { Titratable acidity } \\
(\mathrm{mEq} / \mathrm{l})\end{array}$ & $\mathrm{pH}$ \\
\hline Ethanol group $(2 \mathrm{ml})$ & $103.40 \pm 11.97$ & - & 320 & 2.5 \\
\hline Std. I, pantoprazole (50 mg/kg) & $67.20 \pm 8.027$ & 35 & 24 & 6.98 \\
\hline Std. II, misoprostol sodium ( $20 \mu \mathrm{g} / \mathrm{kg})$ & $72.20 \pm 13.29$ & 30.17 & 24 & 6.98 \\
\hline Low dose of fenugreek extract $(200 \mathrm{mg} / \mathrm{kg})+$ ethanol & $84.00 \pm 9.072$ & 18.70 & 56 & 5.03 \\
\hline Medium dose of fenugreek extract $(600 \mathrm{mg} / \mathrm{kg})+$ ethanol & $58.20 \pm 8.224^{*}$ & 43.71 & 48 & 6.03 \\
\hline High dose of fenugreek extract $(1000 \mathrm{mg} / \mathrm{kg})+$ ethanol & $34.00 \pm 11.92^{*}$ & 67.11 & 160 & 4.45 \\
\hline Normal $(2 \mathrm{ml})$ & NIL & NIL & 160 & 4.6 \\
\hline
\end{tabular}

*Indicates significance with respect to positive control group 
TABLE 3: DOCK SCORES OF FENUGREEK CONSTITUENT ON INTERACTION WITH $\mathrm{H}^{+} / \mathrm{K}^{+}$ATPase

\begin{tabular}{lccc}
\hline Compound & Total score & Crash score* $^{*}$ & Polar score $^{* *}$ \\
\hline Vitexin-7-O-glucoside & 6.17 & -2.26 & 6.02 \\
Vicenin-2 & 6.1 & -1.85 & 6.99 \\
Isovitexin & 5.35 & -1.36 & 2.31 \\
Luteolin & 5.19 & -0.43 & 3.63 \\
Orientin & 5.1 & -1.47 & 4.05 \\
Sarsasapogenin & 4.8 & -0.75 & 0 \\
Isoorientin & 4.4 & -1.85 & 2.63 \\
Neotigogenin & 4.35 & -0.57 & 0 \\
Diosgenin & 4.26 & -1.47 & 1.47 \\
Tricin & 4.17 & -0.46 & 1.64 \\
Yuccagenin & 3.45 & -2.44 & 1.16 \\
Gitogenin & 3.45 & -1.19 & 0.002 \\
Quercetin & 3.22 & -0.39 & 3.14 \\
Naringenin & 2.97 & -0.42 & 2.15 \\
\hline
\end{tabular}

${ }^{*}$ Crash scores close to 0 are favourable negative numbers indicate penetration; **Polar score indicates the degree of $\mathrm{H}$-bonding for a given molecule; molecules with low polar scores were excluded from further screening

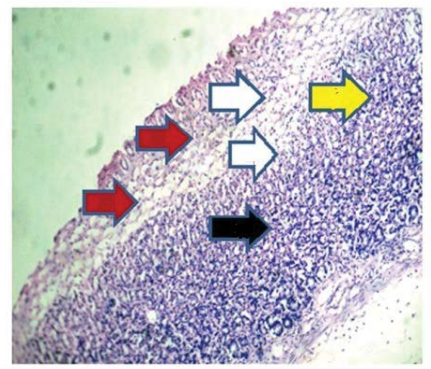

$\mathbf{a}$

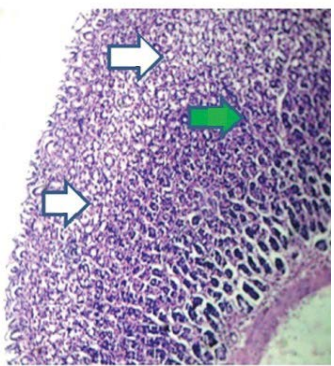

b

Fig. 3: Histopathology of tissue

(a) Ethanol positive control, (b) tissue post treatment with fenugreek extracts $(1000 \mathrm{mg} / \mathrm{kg}) . \Rightarrow$ Haemorrhage, $\Rightarrow$ inflammation, $\Rightarrow$ necrosis, $\Rightarrow$ degeneration, $\Rightarrow$ oedema

a)

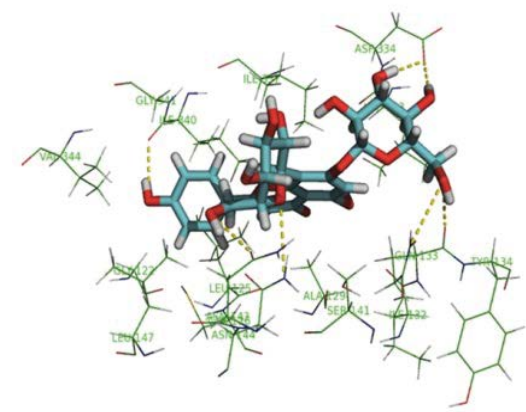

c)

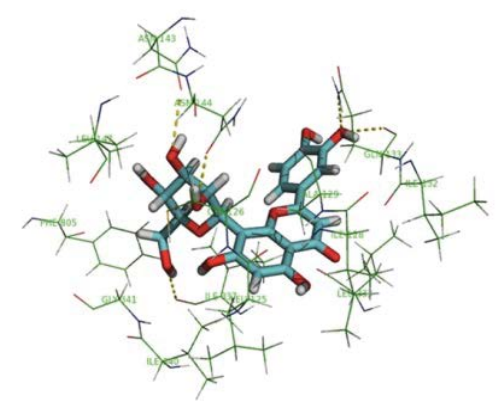

b)

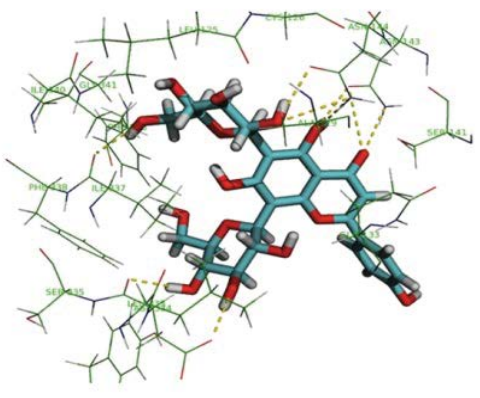

d)

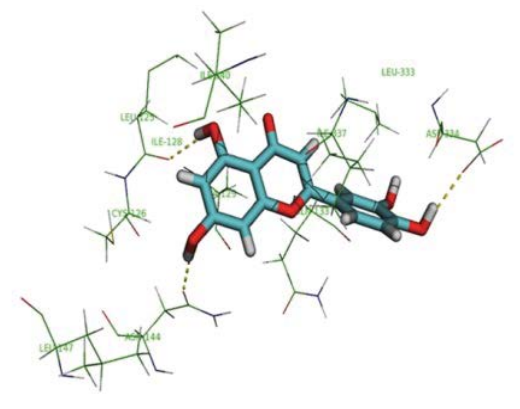

Fig. 4: Interactions of active constituents with $\mathrm{H}^{+} / \mathrm{K}^{+}$ATPase (a) Vitexin 7-O-glucoside, (b) vicenin 2, (c) orientin, (d) luteolin 
The flavonoid constituents during in silico analysis showed remarkable degree of interaction with $\mathrm{H}^{+} / \mathrm{K}^{+}$ ATPase receptor binding site. Thus, this integrated study using in vitro, in vivo and in silico models demonstrates the promising therapeutic potential of fenugreek seed extract as gastroprotective and indicates scope for isolation of individual components of fenugreek seed extract to discover effective, safe and economical gastroprotective agents.

\section{Acknowledgments:}

The authors are grateful to Blue Cross Laboratories Ltd, Mumbai, for providing gift sample of pantoprazole, Dr. N. Sivaprasad, Retired Senior General Manager at BRIT for helping in statistical evaluation of in vivo data, Dr. Siddharth Sabale for conducting the histopathological analysis of the gastric tissue and Elvis Martis and Rohit Chaudhari, Research students at Bombay College of Pharmacy for timely inputs related to in silico data.

\section{Financial support and sponsorship:}

Nil.

\section{Conflict of interest:}

There are no conflicts of interest.

\section{REFERENCES}

1. Skaltsa H. Chemical Constituents in Fenugreek-The Genus Trigonella. In: Petropoulos GA, editor. Medicinal and Aromatic Plants - Industrial Profile. Boca Raton, Florida: CRC Press; 2003, p. 132-61.

2. Pandian SR, Anuradha CV, Vishwanathan P. Gastroprotective effect of Fenugreek seeds (Trigonella foenum graecum) on experimental gastric ulcers in rats. J Ethnopharmacol 2002;81:393-7.

3. Al-dalain S, El-Kutry MS, Ibrahim HS. Inhibitory effects of aqueous extracts of barley and fenugreek on ulcer induction in rats. World Appl Sci J 2008;5:332-9.

4. Helmy HM. Study the effect of fenugreek seeds on gastric ulcer in experimental rats. World J Dairy Food Sci 2011;6:152-8.

5. Zheng H, Shah PK, Audus KL. Evaluation of antiulcer agents with a human adenocarcinoma cell line (AGS). Int J Pharm 1996;129:103-12.

6. Singh S, Sharma. DK. In silico modelling in conjunction with natural products: Paving the way for rational drug-design. Biotechnol Mol Biol Rev 2011;6:88-93.

7. Ekins S, Mestres J, Testa B. In silico Pharmacology for drug discovery applications to targets and beyond. Br J Pharmacol 2007;152:21-37.

8. Debaranjan D, Shanbhag T. A study of antiinflammatory activity of alcoholic extract of seeds of Trigonella foenum graceum (fenugreek) on Wistar strain rat. IJPRD 2010;9:81-5.
9. Jainu M, Devi CS. Antiulcerogenic and ulcer healing effects of Solanum nigrum (L) on experimental ulcer models: Possible mechanism for the inhibition of acid formation. J Ethnopharmacol 2006;104:156-63.

10. Kim CG, Watts JA, Watts A. Ligand docking in the gastric $\mathrm{H}^{+} / \mathrm{K}^{+}$-ATPase: homology modeling of reversible inhibitor binding sites. J Med Chem 2005;48:7145-52.

11. Eswar N, Webb B, Marti-Renom MA, Madhusudhan MS, Eramian D, Shen MY, et al. Comparative protein structure modeling using Modeller. Curr Protoc Bioinformatics 2006;5.6:1-47.

12. Jorgensen AM, Tagmose L, Jorgensen AMM, Topiol S, Sabio $\mathrm{M}$, Gundertofte K, et al. Homology modeling of the serotonin transporter: insights into the primary escitalopram-binding site. Chem Med Chem 2007;2:815-26.

13. Shen MY, Sali A. Statistical potential for assessment and prediction of protein structures. Protein Sci 2006;15:2507-24.

14. Larkin M, Blackshields G, Brown NP, Chenna R, McGettigan $\mathrm{PA}, \mathrm{McWilliam} \mathrm{HV}$, et al. Clustal $\mathrm{W}$ and Clustal X version 2.0. Bioinformatics 2007;23:2947-8.

15. Luthy R, Bowie JU, David E. Assessment of protein models with three-dimensional profiles. Nature 1992;356:83-5

16. Mark P, Nilsson L. Structure and dynamics of the TIP3P, SPC and SPC/E Water Models at 298 K. J Phys Chem 2001;105:9954-60.

17. Abe K, Tani K, Nishizawa T, Fujiyoshi Y. Inter-subunit interaction of gastric $\mathrm{H}^{+} / \mathrm{K}^{+}$-ATPase prevents reverse reaction of the transport cycle. EMBO J 2009;28:1637-43.

18. Abe K, Tani K, Fujiyoshi Y. Conformational rearrangement of gastric $\mathrm{H}^{+} / \mathrm{K}^{+}$-ATPase induced by an acid suppressant. Nat Commun 2011;2:155.

19. Jain AN. Scoring noncovalent protein-ligand interactions: A continuous differentiable function tuned to compute binding affinities. J Comput Aided Mol Des 1996;10:427-40.

20. Welch W, Ruppert J, Jain AN. Hammerhead: fast, fully automated docking of flexible ligands to protein binding sites. Chem Biol 1996;3:449-62.

21. Mutoh H, Hiraishi H, Ota S, Yoshida H, Ivey K, Terano A, et al. Protective role of intracellular glutathione against ethanol-induced damage in cultured rat gastric mucosal cells. Gastroenterology 1990;98:1452-9.

22. Zayachkivska OS, Konturek D. Drozdowicz PC, Konturek T, Brzozowski MR, Ghegotsky. Gastroprotective effects of flavonoids in plant extracts. J Physiol Pharmacol 2005;56:219-31.

23. Matsuda H, Pongpiriyadacha Y, Morikawa T, Kishi A, Kataoka S. Protective effects of steroid saponins from paris polyphylla var. yunnanensis on ethanol- or indomethacin induced gastric mucosal lesions in rats: structural requirement for activity and mode of action. Bioorg Med Chem Lett 2003;13:1101-6.

24. Madhava Naidu M, Shyamala BN, Pura Naik J, Sulochanamma G, Srinivas P. Chemical composition and antioxidant activity of the husk and endosperm of fenugreek seeds. Food Sci Tech 2011;44:451-6.

25. Puurunen J, Karppanen H. Effects of ethanol on gastric acid secretion and gastric muoosal cyclic amp in the rat. Lif Sci 1975;16:1513-20.

26. Borrelli F, Izzo AA. The plant kingdom as a source of anti ulcer remedies. Phytother Res 2000;14:581-91. 